\title{
Rho Guanine Nucleotide Exchange Factor 28
}

National Cancer Institute

\section{Source}

National Cancer Institute. Rho Guanine Nucleotide Exchange Factor 28. NCI Thesaurus. Code C97267.

Rho guanine nucleotide exchange factor 28 (1705 aa, $192 \mathrm{kDa}$ ) is encoded by the human ARHGEF28 gene. This protein plays a role in the mediation of guanine nucleotide exchange for the GTPase transforming protein Rho A. 